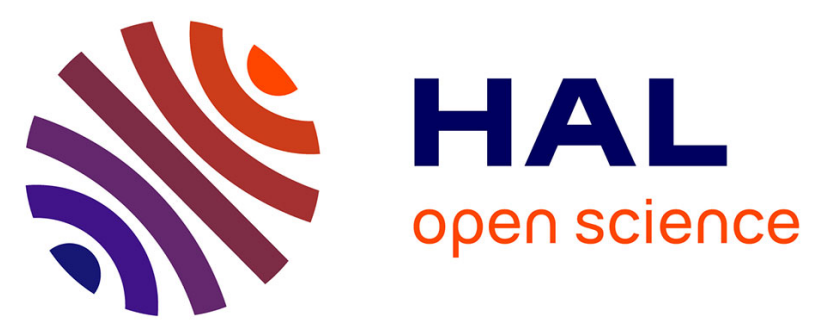

\title{
Dynamic sensory description of Rioja Alavesa red wines made by different winemaking practices by using Temporal Dominance of Sensations
}

Iñaki Etaio, Sophie Meillon, Francisco J Pérez-Elortondo, Pascal Schlich

\section{- To cite this version:}

Iñaki Etaio, Sophie Meillon, Francisco J Pérez-Elortondo, Pascal Schlich. Dynamic sensory description of Rioja Alavesa red wines made by different winemaking practices by using Temporal Dominance of Sensations. Journal of the Science of Food and Agriculture, 2016, 96 (10), pp.3492-3499. 10.1002/jsfa.7533 . hal-01393551

\section{HAL Id: hal-01393551 https://u-bourgogne.hal.science/hal-01393551}

Submitted on 6 Oct 2017

HAL is a multi-disciplinary open access archive for the deposit and dissemination of scientific research documents, whether they are published or not. The documents may come from teaching and research institutions in France or abroad, or from public or private research centers.
L'archive ouverte pluridisciplinaire HAL, est destinée au dépôt et à la diffusion de documents scientifiques de niveau recherche, publiés ou non, émanant des établissements d'enseignement et de recherche français ou étrangers, des laboratoires publics ou privés. 


\title{
Dynamic sensory description of Rioja Alavesa red wines made by different winemaking practices by using Temporal Dominance of Sensations
}

\author{
Iñaki Etaio, ${ }^{a}$ Sophie Meillon, ${ }^{b, c, d}$ Francisco J Pérez-Elortondo ${ }^{a}$ and \\ Pascal Schlich ${ }^{b, c, d}$
}

\begin{abstract}
BACKGROUND: Although sensory description of wines in scientific literature is very large, there is an evident lack of studies describing wines from a dynamic approach. The objective of this study was to describe the evolution of the sensations perceived in red wines from Rioja Alavesa by using Temporal Dominance of Sensations (TDS) and also to compare wines made with the two winemaking procedures used in Rioja Alavesa: carbonic maceration (CM) and destemming (DS).

RESULTS: Ten sensory attributes were evaluated in eight wines (four CM and four DS wines) in triplicate by a panel of 16 trained assessors. Red/black berry and woody aromas were dominant firstly, whereas heat, astringent, bitter and pungent sensations were dominant later. CM wines showed higher dominance for woody, spicy, pungent and acid sensations and lower dominance for red/black berry aroma and astringency than DS wines.

CONCLUSION: This study is the first to describe Rioja wines from a dynamic approach and it also provides information about the dynamic sensory differences between wines made by CM or by DS. In this sense, this work shows the usefulness of TDS to describe and differentiate wines and to provide additional information to the conventional static descriptive analysis.
\end{abstract}

Keywords: TDS; Rioja wine; carbonic maceration; sensory analysis; Tempranillo

\section{INTRODUCTION}

Rioja Alavesa (RA) is one of the three sub-zones in the Rioja wine region included in the Protected Designation of Origin (PDO) Rioja. Among the grape varieties accepted for winemaking, Tempranillo is the predominant one in red wines $(96.36 \%$ of the surface cultivated with red grape varieties). ${ }^{1}$ Most of the red wines are made exclusively with the Tempranillo grape variety or by mixing Tempranillo with other grape varieties in a low proportion (usually lower than 10\%). These minor grape varieties also include some white grape varieties such as Viura (also called Macabeo) which is the main one.

Young wine is the most typical wine in RA and it has been traditionally made by the carbonic maceration (CM) technique. CM is also used in different European regions to make traditional wines, such as Médoc, Bordeaux, Beaujolais or Provence.,3 The maintenance of many small, family wineries in RA has perpetuated this practice although the use of destemming (DS), i.e. winemaking by crushing the grapes before fermentation, is progressively displacing CM.

CM was described for the first time by Flanzy ${ }^{4}$ and it refers to placing the entire grapes in a vat within a $\mathrm{CO}_{2}$ atmosphere (anaerobiosis) for several days so that several enzymatic reactions take place without yeast participation: ethanol production (until 20-30 $\mathrm{mL} \mathrm{L}^{-1}$ ), malic acid consumption and polyphenol transfer from skin to the pulp. Then, the grapes break down because of the internal pressure and the fermentation by yeast starts.

Actually, CM practised in RA is not a strict CM since some grapes break when they are placed in the vat (thus initialising the fermentation by yeast, so both phenomena take place simultaneously),

\footnotetext{
Correspondence to: Iñaki Etaio, Laboratorio de Análisis Sensorial Euskal Herriko Unibertsitatea (LASEHU), Department of Pharmacy and Food sciences. Lactiker (Research team on quality and safety of foods of animal origin). Lascaray Research Center, Universidad del País Vasco - Euskal Herriko Unibertsitatea - University of the Basque Country (UPV/EHU), Unamuno etorbidea, 3, 01006 Vitoria-Gasteiz, Spain. E-mail: inaki.etaio@ehu.eus

a Laboratorio de Análisis Sensorial Euskal Herriko Unibertsitatea (LASEHU), Department of Pharmacy and Food Sciences, Lascaray Research Center, Universidad del País Vasco - Euskal Herriko Unibertsitatea - University of the Basque Country (UPV/EHU), Unamuno etorbidea, 3, 01006 Vitoria-Gasteiz, Spain

b INRA, UMR 1324 Centre des Sciences du Goût et de l'Alimentation, 17 rue Sully, F-21000 Dijon, France

c Université de Bourgogne UMR Centre des Sciences du Goût et de l'Alimentation, 17 rue Sully, F-21000 Dijon, France

d CNRS, UMR 6265 Centre des Sciences du Goût et de l'Alimentation, 17 rue Sully, F-21000 Dijon, France
} 
$\mathrm{SO}_{2}$ is added and $\mathrm{CO}_{2}$ is not. ${ }^{5}$ Next, free run must from the grapes and must from pressed clusters are mixed to continue the alcoholic fermentation, usually without the skins. In the DS process, grapes are crushed and fermentation by yeast occurs immediately in contact with skins.

Although RA wines are recognised as high quality wines, scientific reports describing their organoleptic characteristics using sensory panels are very scarce. ${ }^{6}$ Regarding sensory characteristics that differentiate $\mathrm{CM}$ wines from DS wines, the scientific literature is quite general and ambiguous. In addition, the sensory practices used do not always meet the minimum required in scientific sensory analysis. Odour of CM wines has been described as 'distinctive' and 'rich'. ${ }^{3,7,8}$ Sensory attributes frequently used to describe the aromas of these wines are related to fruits, i.e. generic fruit, $5,7,9$ or specific fruit attributes such as strawberry and raspberry ${ }^{10}$ or cherry and kirsch. ${ }^{11}$ Other aromas reported are floral ${ }^{7,9}$ and spicy. ${ }^{12}$

Regarding sensations in mouth, CM wines have been described as soft and velvety $2,5,7,12,13$ but without comparing them directly with wines made by DS. Among the very few studies comparing CM and DS wines by using sensory panels, Fuleki ${ }^{13}$ reported that CM wines from Concord grapes (Vitis labrusca) presented a softer taste and better flavor (lower Concord character) than DS wines made with the same grapes. In the case of Tempranillo wines from RA, Etaio et al. ${ }^{14}$ described CM wines as stronger in red berry odour and aroma, alcoholic aroma and acidity, and lower in licorice and tree fruit odour than DS wines.

In all the works found in the scientific literature sensory description of $\mathrm{CM}$ wines has been made by the traditional approach, that is, by evaluating the product in a static way, without considering the evolution of the sensations in the mouth throughout the time. The Temporal Dominance of Sensations (TDS) technique ${ }^{15-17}$ allows the sensory characteristics elicited by food products to be described by taking into account the temporal dimension. TDS consists of identifying and rating sensations perceived as dominant throughout the tasting and enables the different sensations to be evaluated simultaneously. After introducing the food or drink into the mouth, each assessor has to indicate all the sensory descriptors (attributes) perceived as dominant among a list of attributes displayed on the computer screen throughout the evaluation, and also she/he has to rate their intensity on a continuous scale. Data collected from all the assessors are then analysed as described in Labbe et al. ${ }^{18}$ and Pineau et al. ${ }^{15}$ to calculate dominant rates for each attribute.

The TDS technique has been successfully applied to evaluate several food products and drinks, such as gels containing odorants, ${ }^{18}$ alcoholic beverages, ${ }^{19}$ candies, $^{20}$ extra-virgin olive oil with pureed bean and tomatoes ${ }^{21}$ blackcurrant squashes, ${ }^{22}$ coffee, $^{23}$ fish sticks, ${ }^{24}$ beer, ${ }^{25}$ ice-creams ${ }^{26}$ or wine. ${ }^{27-30}$ For a more detailed list of studies applying TDS see Di Monaco et al. ${ }^{16}$

The main objective of the present work was to describe the temporal sensory perception in mouth of eight red wines from Rioja Alavesa using the TDS method and to study the sensory differences related to the winemaking process, i.e. carbonic maceration versus destemming.

\section{EXPERIMENTAL \\ Wines}

Eight young red wines from different wineries from RA were analysed in the study. Four wines were made by $\mathrm{CM}$ and four wines by DS. In each group of wines (CM and DS), three wines were made exclusively with the Tempranillo variety and the other wine was made with Tempranillo but also adding Viura variety grapes (approximately $10 \%$ of the total grape weight). This wine with Viura grapes was included in each group since adding a small percentage of white grape varieties to make red wine is a usual practice carried out by many wineries from RA and it is expressly accepted in the regulations of PDO Rioja. ${ }^{31}$ As wines were produced to be commercialised as PDO Rioja, enological practices followed by the wineries fitted the rules of this PDO. All the wines underwent malolactic fermentation. Bottles $(750 \mathrm{~mL})$ were picked up directly from the wineries and kept laid down in a cellar $\left(12 \pm 3^{\circ} \mathrm{C}\right.$ and $90 \pm 5 \%$ of relative humidity) until being analysed. At the laboratory, wines were stored at $10^{\circ} \mathrm{C}$. Twenty-four hours before being served, wines were put at room temperature in order to reach the serving temperature of $21 \pm 1^{\circ} \mathrm{C}$. Wine bottles were opened $1 \mathrm{~h}$ before the evaluation. The main chemical characteristics of the wines are shown in Table 1.

\section{Assessors}

Sixteen French assessors (nine women and seven men) aged 29-65 years (mean age 45 years) participated in this study which took place at the Centre des Sciences du Goût et de I'Alimentation (CSGA) in Dijon (France). They were selected according to their results in previous sensory discrimination, ranking and recognition tests and had recently participated in a TDS panel training and red wine sensory profile (sixteen 1-h sessions) for 3 months. They were paid for their involvement in the study.

\section{Training sessions}

Assessors were trained during three 1-h sessions to TDS evaluation of the RA wines. In the first session descriptive sensory attributes were generated for the eight wines of the study. Assessors were instructed about the tasting protocol: ${ }^{28}$ at zero seconds, put the wine in mouth; at $12 \mathrm{~s}$, inspire three times drawing air through the wine; at $20 \mathrm{~s}$, click the tongue three times and wait until no more sensations are perceived. Throughout the evaluation of each sample, assessors had to write down all the mouth sensations they perceived as dominant. The 10 more cited terms were selected and kept for further TDS evaluations. The two following sessions were dedicated to check the appropriateness of the attribute list, to define the sensory reference corresponding to each attribute and to train the panel in sample evaluation by using TDS method. In both sessions sensory references and wine samples were evaluated and discussed in order to reach a consensus about the attributes perceived in the samples and the references that best reproduce them. The final 10 attributes selected for the study (four aromas and six gustative and mouth-feel sensations) and the composition of the sensory references are shown in Table 2.

\section{Wine evaluation by TDS}

Wine evaluations by TDS took place in isolated sensory booths at standardised temperature $\left(20 \pm 1^{\circ} \mathrm{C}\right)$ and under red light to mask wine colour. Wine samples were presented in plastic opaque cups $(10 \mathrm{~mL})$ coded randomly with three digits.

Evaluations were carried out in three 1-h sessions in order to have three replications. In each session, the eight wines of the study were monadically presented according to a Williams Latin Square design balanced for order and carry-over effects.

Data acquisition was achieved with Fizz Software (BIOSYSTEM, Couternon, France) with a period of $500 \mathrm{~ms}$. The list of the 10 attributes was displayed on a computer screen associated with unstructured scales $(30 \mathrm{~cm})$, ranging from weak (left) to strong 
Table 1. Main chemical characteristics of the wines (mean values \pm standard deviation) ${ }^{\mathrm{a}}$

\begin{tabular}{lcccccc} 
Wine & Winemaking technique & Grape variety & Ethanol $\left(\mathrm{cL} \mathrm{L}^{-1}\right)^{\mathrm{b}}$ & $\mathrm{pH}^{\mathrm{c}}$ & $\begin{array}{c}\text { Total acidity } \\
\left.(\mathrm{g} \text { tartaric acid L })^{-1}\right)^{\mathrm{d}}\end{array}$ & Total polyphenol index $^{\mathrm{e}}$ \\
\hline CM1 & Carbonic maceration & Tempranillo & $13.69 \pm 0.13$ & $3.75 \pm 0.01$ & $4.32 \pm 0.13$ & $55.25 \pm 0.96$ \\
CM2 & Carbonic maceration & Tempranillo & $14.48 \pm 0.17$ & $3.67 \pm 0.02$ & $4.45 \pm 0.17$ & $62.75 \pm 1.26$ \\
CM3 & Carbonic maceration & Tempranillo & $13.54 \pm 0.13$ & $3.80 \pm 0.01$ & $4.08 \pm 0.13$ & $59.25 \pm 0.96$ \\
CM4 & Carbonic maceration & Tempranillo + Viura & $13.96 \pm 0.14$ & $3.61 \pm 0.01$ & $4.27 \pm 0.14$ & $45.75 \pm 0.50$ \\
DS1 & Destemming & Tempranillo & $13.24 \pm 0.18$ & $3.75 \pm 0.01$ & $4.55 \pm 0.18$ & $63.50 \pm 1.29$ \\
DS2 & Destemming & Tempranillo & $14.13 \pm 0.15$ & $3.63 \pm 0.01$ & $4.67 \pm 0.15$ & $64.25 \pm 0.96$ \\
DS3 & Destemming & Tempranillo & $13.42 \pm 0.06$ & $3.89 \pm 0.01$ & $4.13 \pm 0.06$ & $70.75 \pm 1.26$ \\
DS4 & Destemming & Tempranillo + Viura & $14.03 \pm 0.15$ & $3.58 \pm 0.01$ & $4.83 \pm 0.15$ & $57.25 \pm 0.96$ \\
\hline
\end{tabular}

a Analysis carried out at the Official Laboratory of Araba County Council, one of the three official laboratories authorised to analyse wines protected by DOC Rioja. ${ }^{32}$ In order to check accuracy internal standards and one repeated sample were used in the analysis of each parameter, according to the standardised laboratory protocol.

b Determined by spectrophotometry of near infrared reflectance with Technicon InfraAnalyzer 400 (Technicon Instruments Corporation, Tarrytown, NY, USA) as described by Dumolin et al. ${ }^{33}$

' Determined by potentiometry. By potentiometry with $\mathrm{H}$-plus equipment (Technicon), after calibration with $\mathrm{pH}$ standards.

d Determined by acid-base titration. Potentiometric titration up to $\mathrm{pH} 7 .^{34}$

e Determined by spectrophotometry; absorbance at $280 \mathrm{~nm}^{34}$

Table 2. Sensory attributes evaluated in the wines and reference composition
Sensory attribute

Aromas

Red/black berries

Spicy

Banana

Tastes and mouthfeel sensations

Acid

Bitter

Astringent

Heat (alcohol)

Pungent

Sweet
Woody/roasted
Reference composition

$8 \mathrm{~g}$ oak chips maintained two days in $1 \mathrm{~L}$ of water

Strawberry (Monin), cherry (Monin) and

blackcurrant syrups

(Vedrenne) at a

concentration of

$50 \mathrm{~mL} \mathrm{~L}^{-1}$ water (each one)

$80 \mathrm{~mL}$ cinnamon syrup (Monin) $\mathrm{L}^{-1}$ water

$80 \mathrm{~mL}$ green banana syrup (Monin) $\mathrm{L}^{-1}$ water

$1 \mathrm{~g}$ citric acid $\mathrm{L}^{-1}$ water

0.08 g quinine chlorhydrate $\mathrm{L}^{-1}$ water

$0.6 \mathrm{~g}$ tannic acid $\mathrm{L}^{-1}$ water

$70 \mathrm{~mL}$ ethanol $\mathrm{L}^{-1}$ water

$-$

$8 \mathrm{~g}$ sucrose $\mathrm{L}^{-1}$ water (right). The order of the attributes in the list was randomised across assessors to balance the fact that first attributes of the list could be more often cited. ${ }^{35}$

Assessors put all the cup content in mouth and clicked the 'start' button to start the temporal sensory evaluation. Once the chronometer started, they identified and rated the intensity of the sensations they perceived as dominant while performing the tasting protocol. Score recording extended throughout $120 \mathrm{~s}$ although when not perceiving sensations anymore, assessors had to click 'stop' button. A 2 min break was established between samples to eliminate residual sensations by rinsing the mouth with unsalted crackers and Evian water.

\section{Data analysis}

Data analysis was carried out as described by Meillon et al. ${ }^{28}$ for producing the TDS curves for each wine and the TDS curves of differences between CM and DS wines. Curves were produced by importing the Fizz data into the TimeSens software (www.timesens.com).

The dominant rates of the different attributes are calculated for each wine by dividing the number of citations of each attribute (over all assessors and replications) by the total number of evaluations (number assessors $\times$ number replications). Since an assessor can have only a single dominant attribute at each time, the sum of the dominance rates over attributes is equal to 1 at each time. The higher the dominant rate, the better is the agreement among assessors (i.e. if 10 of the 16 assessors had marked an attribute as dominant at the same time, the dominance rate of this attribute is 10/16, which indicates a better agreement than, for instance, five assessors coinciding in an attribute, so with a dominance rate of 5/16).

The dominance rates of each attribute are then smoothed along time to produce a time-dominance curve. The different curves for a given wine are then displayed on a graph that also includes 'chance level' and 'significance level' curves. The 'chance level' line represents the dominance rate that an attribute can obtain by chance ( $1 /$ number of attributes). The 'significance level' line, based on a binomial test, expresses the smallest value of the proportion being significantly $(P \leq 0.10)$ higher than the 'chance level'. When the curve of an attribute overcomes this significance level, it is considered as significantly dominant. In this manner, the sequence of the dominant sensations perceived in a product can be described.

In addition, TDS difference curves showing the attributes that are different between CM and DS wines were produced as described by Pineau et al. ${ }^{15}$ These curves are drawn by subtracting time by time dominance rates from one product to another one. TDS difference curves were plotted only when a significant $(P \leq 0.10)$ difference was observed between the average dominance rate of the four CM wines and the average dominance rate of the four DS wines.

The table composed of dominance durations of products by subjects as observations and attributes as variables was analysed by 
Canonical Variate Analysis (CVA). The first two canonical variates were displayed as a biplot with superimposition of the $90 \%$ confidence ellipses of product means. CVA was complemented by $T^{2}$ Hotelling tests to compare the products two by two multi-variately based on their dominance durations. CVA was also carried out by using TimeSens software.

\section{RESULTS AND DISCUSSION \\ Dynamic descriptions of the wines}

The attributes selected to be evaluated in the RA wines of the present study (Table 2) did not fit, to a certain extent, the attributes previously reported for young red wines from Rioja Alavesa. ${ }^{6}$ It could be explained by the fact that TDS is a sensory approach different to the conventional descriptive analysis, which does not consider expressly the evolution of sensations. But it could also be explained in some sense by the cultural differences between panels from different regions (Basque Country and Burgundy in this case), as reported by several authors. In fact, Drake et al. ${ }^{36}$ reported differences in the usage of several terms to describe Cheddar cheeses among panels from Ireland, New Zealand and USA, and found some attributes that likely displayed distinct cultural influences. Also, Strauss ${ }^{37}$ reported cultural variations in the taste patterns used in Japan, Korea and USA, and Tu et al. ${ }^{38}$ found cultural specificities among Vietnamese and French panels when describing the aroma of yogurts.

TDS curves for the eight wines analysed are shown in Fig. 1. The attributes more consistent at panel level (curves over the significant level line; $P=0.10$ ), so valid to describe the wines in a general manner, were heat, red/black berries aroma and astringent (significantly dominant in eight, seven and seven wines, respectively). Bitter was significantly dominant in five wines, woody aroma and pungent in four wines and acid in three wines. Spicy and banana aromas and sweet were not significantly dominant in any wine. To summarise, three attribute groups can be clearly differentiated regarding the evolution of the sensations perceived in the mouth: attributes with dominance in all or almost all the wines (heat, red/black berries aroma and astringent), attributes with dominance in approximately half of the wines (bitter, woody aroma, pungent and acid), and attributes without any dominance (spicy, banana aroma and sweet).

Regarding the sequences of dominant sensations in the wines as a whole, aromas (red/black berries and woody) were dominant at the beginning of the tasting experience while gustatory and trigeminal sensations (bitter, heat, astringent, pungent and acid) were dominant later. This clear separated perception order has not been observed in other studies describing wines by TDS method, where the maximum dominance peaks of these different sensations appeared mixed and also, in some cases, with taste and trigeminal sensations perceived as dominant sooner than aromas (Meillon et al. in Syrah and Merlot wines ${ }^{28,29}$ and Pessina et al. in Falanghina and Falanghina and Muscat mixed wine ${ }^{39}$ ).

The time when the dominance peak was highest was quite similar for red/black berry and for woody aromas, ranging from 8 to $14 \mathrm{~s}$ and from 7 to $11 \mathrm{~s}$, respectively (with the exception of red/black berry aroma in wines DS1 and DS3, with maximum peaks at 26 and $20 \mathrm{~s})$. Curves above the significant level for taste and trigeminal sensations appeared later than aromas and were broader, remaining significantly dominant for a longer time. With the exception of pungent (with a maximum dominance peak ranging from 29 to $35 \mathrm{~s}$ ), there was a quite high dispersion among wines regarding the times when the dominance was maximum (heat from 21 to $46 \mathrm{~s}$, astringent from 14 to $38 \mathrm{~s}$ and bitter from 16 to $30 \mathrm{~s}$ ). Also, the order of the maximum peaks of these sensations throughout the time varied according to each wine. Despite this, some general trends were observed: pungent presented a dominance peak quite regular around 29-35 s; bitter, when significantly dominant, was the first or second maximum peak; and heat was the last maximum peak for majority of the wines (in seven of the eight wines).

\section{Dynamic sensory differences between carbonic maceration wines and destemming wines}

When comparing DS and CM wines (Fig. 2), significant differences $(P \leq 0.10)$ were found for several attributes. Regarding the aromas, DS wines presented a significantly higher dominance of red/black berry aroma compared with $\mathrm{CM}$ wines in the time interval from 15 to $30 \mathrm{~s}$. On the other hand, CM wines presented a higher dominance for woody and spicy aromas at 5-8 and 15-22 s, respectively. Although spicy aroma did not present a significant dominance in any wine, when comparing both kinds of wines the differences were significant. The higher dominance of red/black berry aroma in DS wines in comparison with CM wines was unexpected. Although there are no other similar studies of TDS application to compare with, the very limited number of scientific reports comparing CM and DS wines by using conventional descriptive analysis indicate that $\mathrm{CM}$ wines are characterised by higher fruity and, specifically, red berry aromas. Indeed, Etaio et al. ${ }^{14}$ found that $\mathrm{CM}$ wines presented a significantly higher red berry aroma than DS wines (there were not significant differences for black berry aroma). Versini and Tomasi $^{10}$ described CM wines as higher in strawberry and raspberry in comparison with non-CM wines as well. Also, the higher fruity character of CM wines reported by several authors ${ }^{5,7,9}$ has not been observed in the present study. The higher dominance for red/black berry aroma in DS wines could be explained for later and broader peaks over the significance line for this attribute in comparison with CM wines (Fig. 1). In this sense, the use of a dynamic approach seems to reveal a small time difference in the perception of this sensation as dominant, which could not be noticed when using the conventional descriptive analysis. This observation would support the interest of using both kind of analysis to better understand the sensations perceived in mouth when evaluating a food product.

Regarding taste and trigeminal sensations, heat, the unique attribute that resulted in being significantly dominant in the eight wines, did not present differences among DS and CM wines. Thus, this attribute contributed to describing the sensations elicited in mouth by these wines but not to discriminating among these two winemaking practices. In relation to heat sensation, Etaio et al. ${ }^{14}$ reported higher intensity for alcoholic sensation in CM wines in conventional descriptive analysis. No additional references about possible differences between CM and DS wines for this sensation (heat, alcoholic, burning) have been found.

In relation to astringency, DS wines presented an evident higher dominance, which extended throughout $25 \mathrm{~s}$. There is no conclusive data about the differences in astringency between CM and DS wines, mainly due to the scarce scientific reports published (all of them using conventional descriptive analysis). In a study assessing wines made with Muscadine grape variety (Vitis rotundifolia Michaux) Carroll ${ }^{12}$ reported lower astringency for $C M$ wines in comparison with DS wines, whereas Etaio et al. ${ }^{14}$ did not find differences in Tempranillo wines from Rioja Alavesa regarding these two winemaking practices.

CM wines presented a slight higher dominance for pungent and for acid sensations during a brief period of time ( 6 and $4 \mathrm{~s}$, 

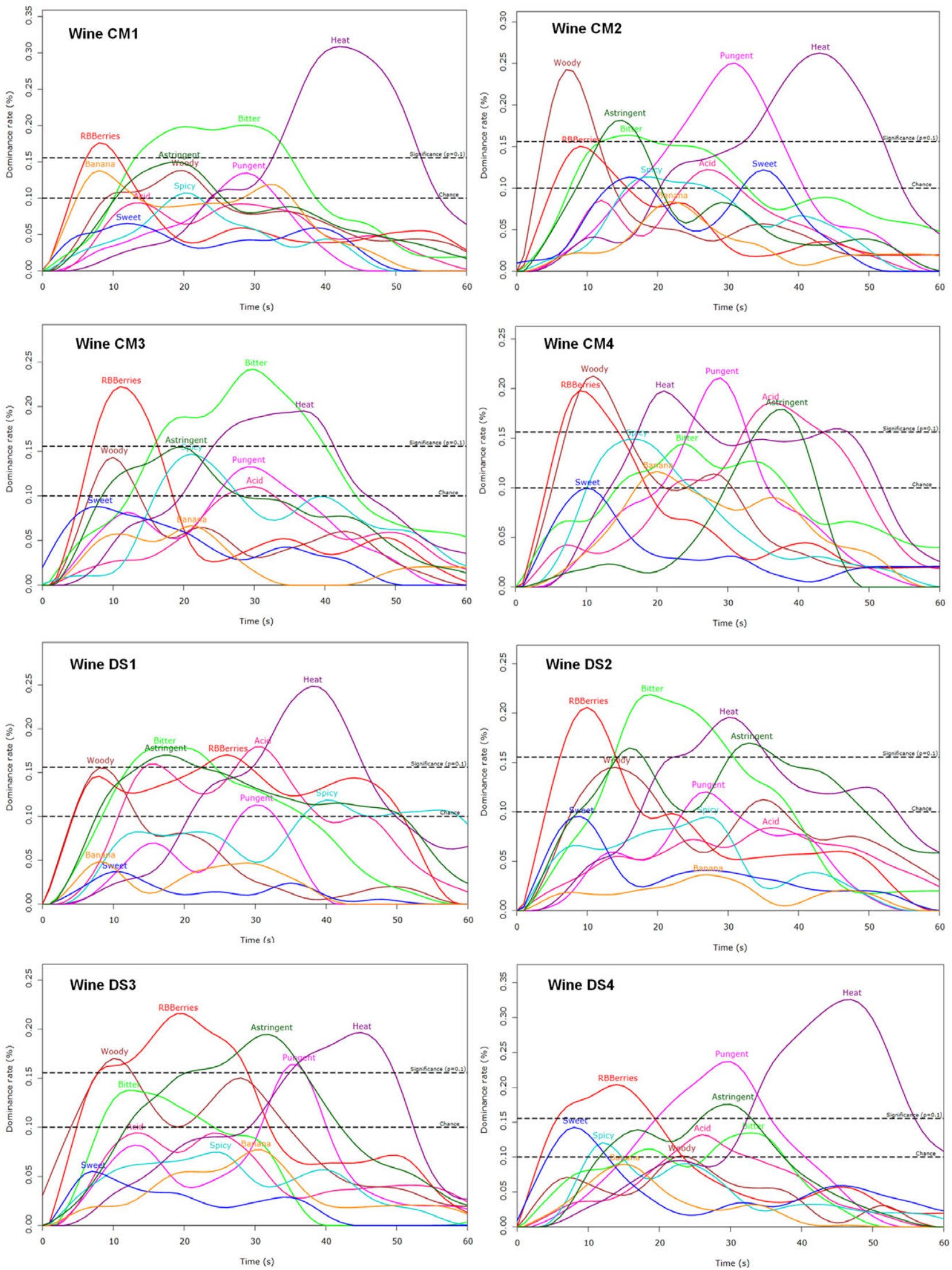

Figure 1. Evolution of dominance of sensory perceptions resulting from TDS for carbonic maceration (CM) and destemming (DS) wines. Curves over the significance level $(P=0.10)$ mean that the attribute is significantly dominant. 


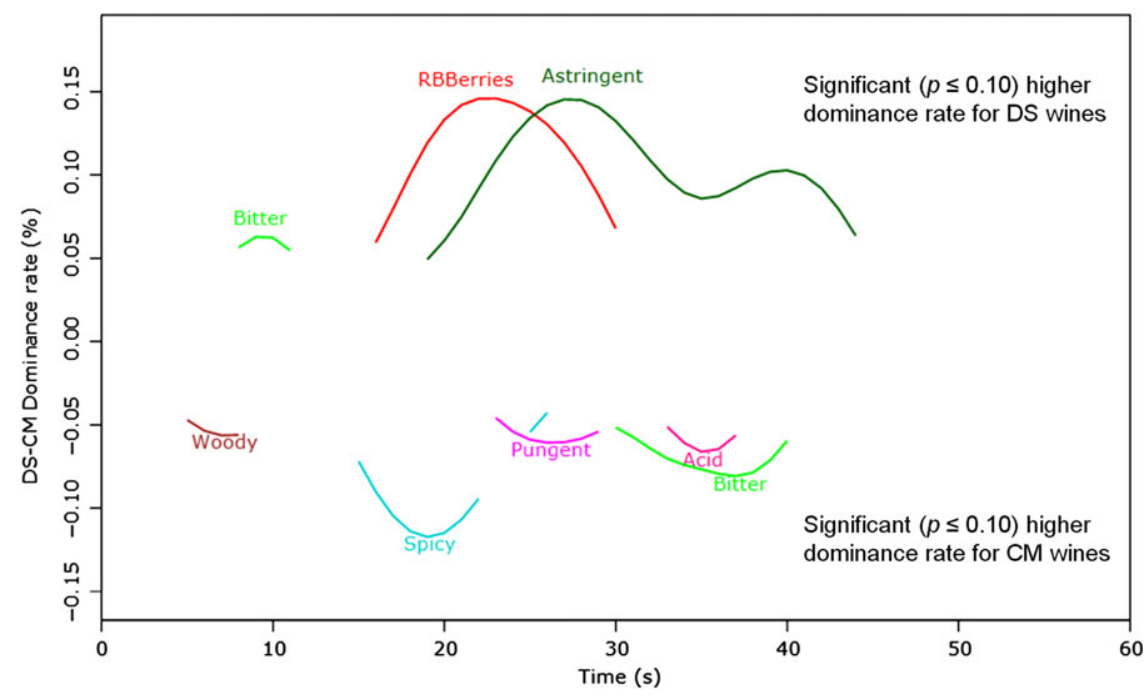

Figure 2. Significant differences $(P \leq 0.10)$ between TDS curves of carbonic maceration (CM) and destemming (DS) wines (upper curves express higher dominance rates for $D S$ wines, and lower curves higher dominance rates for $C M$ wines).

Table 3. CVA Hotelling table for carbonic maceration (CM) and destemming (DS) wines

\begin{tabular}{cccccccc} 
Sample & CM1 & CM2 & CM3 & CM4 & DS1 & DS2 & DS3 \\
\hline CM1 & 1 & 0.623 & 0.477 & 0.475 & 0.005 & 0.144 & 0.003 \\
CM2 & 0.623 & 1 & 0.222 & 0.102 & 0 & 0.035 & 0 \\
CM3 & 0.477 & 0.222 & 1 & 0.598 & 0.037 & 0.093 & 0.008 \\
CM4 & 0.475 & 0.102 & 0.598 & 1 & 0.025 & 0.143 & 0.001 \\
DS1 & 0.005 & 0 & 0.037 & 0.025 & 1 & 0.013 & 0.008 \\
DS2 & 0.144 & 0.035 & 0.093 & 0.143 & 0.013 & 1 & 0.052 \\
DS3 & 0.003 & 0 & 0.008 & 0.001 & 0.008 & 0.471 & 0.471 \\
DS4 & 0.128 & 0.311 & 0.047 & 0.052 & 0.001 & 0.055 & 0.055 \\
\hline
\end{tabular}

Shaded cells mean that there is significant difference between products $(P \leq 0.10)$ and cells without shading mean that there is no significant difference between products $(P>0.10)$.

respectively). References of other authors about differences in pungent sensation between DS and CM wines have not been found. Regarding acid sensation, the mentioned slight higher dominance in CM wines agreed with the results of Etaio et al. ${ }^{14}$

Bitter attribute presented a singular performance, since its dominance was slightly higher for DS (between seconds 8 and 11) and later, from seconds 30 to 40 , higher for CM. No clear explanation of this observation can be formulated but it could be linked to the dominance/lack of dominance of other sensations instead of being a very different perception of bitterness in CM and DS wines.

With regards to the interval when dominance differences between DS and CM wines were significant, Fig. 2 shows that, in general terms, the main differences in attribute dominance took place from 15 to $44 \mathrm{~s}$. So, it seems that it was necessary to have sufficient time after sipping the wine for the sensory differences to be clearly perceived.

A hotelling table from CVA and the corresponding bi-plot for wines and attributes are shown in Table 3 and in Fig. 3, respectively. The two axes represented in Fig. 3 explain $55.59 \%$ of the variance. The main aspect observed in Fig. 3 and Table 3 is that CM wines were very close, overlapping all of them, with no significant $(P>0.10)$ wine-to-wine differences among them, and that, with some exceptions, they differed from DS wines. CM wines were related with attributes such as spicy aroma, bitter, banana aroma, sweet, pungent and, to a less extent, heat and acid. DS wines were more dispersed than CM wines in the bi-plot and there were also many significant wine-to-wine differences among DS wines (10 significant differences vs. two non-significant differences in Table 3). As shown in Fig. 3, wine DS1 was significantly different from the other six wines (with a very slight overlapping surface with CM3), wine DS3 was different from other six wines (the four CM wines and two DS wines), wine DS4 was different from wines DS1 and DS3, and wine DS2 only differed clearly from wine DS1. So, DS wines were more heterogeneous than CM wines regarding their dynamic sensory characteristics. Among DS wines, wine DS2 and wine DS3 were the closest ones, mainly described by astringent, red/black berry aroma and woody aroma. On the projection over these first two axes, wine DS1, the most different from the others, was not clearly differentiated by any attribute dominance (just in a slightly manner by acid sensation) and wine DS4 was mainly related to heat, pungent and, to a certain extent, to sweet sensation.

\section{CONCLUSIONS}

Using TDS to describe red wines from Rioja Alavesa has provided new information about the evolution of the sensations perceived in these wines, which cannot be achieved by static descriptive 


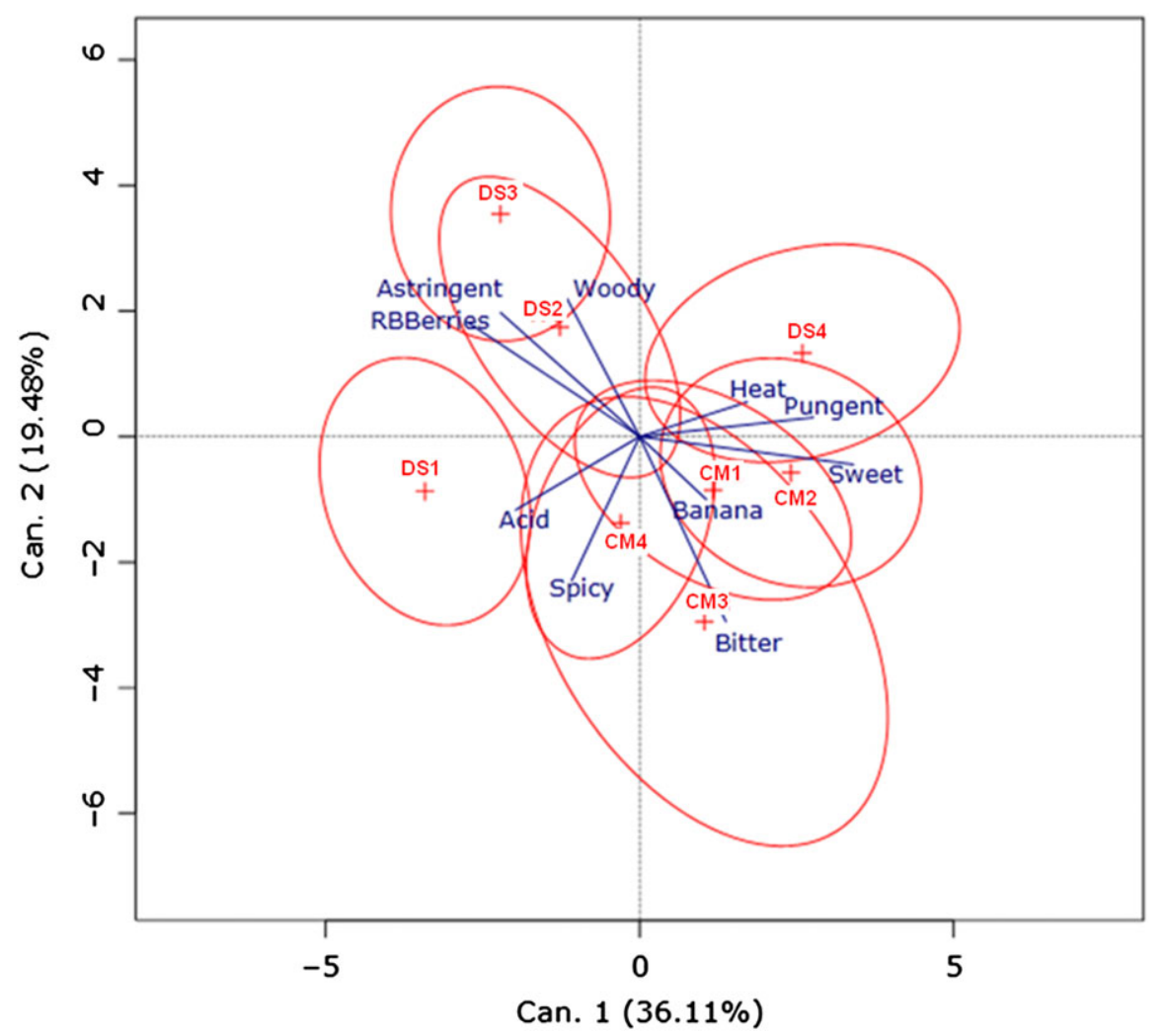

Figure 3. Plot from canonical variate analysis of the wines (CM, carbonic maceration; DS, destemming) and attributes $(P<0.0001$; confidence ellipses at $90 \%)$.

analysis. Results of the application of this method have shown that heat, red/black berries aroma, astringent, bitter, woody aroma, pungent and acid are the main attributes to describe the evolution of the sensations perceived in mouth, although attributes with significant dominance varied to a great extent depending on the wine. It has been also observed that there is a tendency for the aromas to dominate first, and the gustative and trigeminal sensations to dominate later, which constitutes an interesting aspect to be investigated in the future in relation to this method.

Analysis of wines by TDS has enabled the observation of significant differences in the evolution of the sensations in the mouth according to the winemaking used (CM vs. DS). CM wines showed higher dominance for woody and spicy aromas, and pungent and acid sensations, while DS wines showed higher dominance for red/black berry aroma and astringency. This information complements the scarce information available about the differences between wines made by these two winemaking processes, providing the wineries with additional data about the implications of using one winemaking process or the other one. Despite these results, additional studies are still necessary to confirm the observed dynamic differences due to winemaking process in these products. Besides, it would be interesting for further works to consider the cultural effect on the use of attributes to describe the sensations perceived in these kinds of wines.

\section{ACKNOWLEDGEMENTS}

The authors thank Christine Urbano, from Centre des Sciences du Goût et de l'Alimentation, for helping with the panel training and sample preparation.

\section{REFERENCES}

1 Regulatory Council of PDO Rioja (2014), Estadísticas 2013. El Rioja en cifras. Available: http://es.riojawine.com/multimedia/files/ publicaciones/Estadisticas_Rioja_2013.pdf [27 July 2015].

2 Ribéreau-Gayon J, Peynaud E, Ribéreau-Gayon P and Sudraud P, Traité d'Oenologie. Sciences et Techniques du Vin. Tome III. Vinifications. Transformations du vin. Éditions Dunod, Paris (1976).

3 Carnacini A and Del Pozzo A, Caratteristiche di vini ottenuti mediante macerazione carbonica. L'enotecnico 21:1115-1119 (1985).

4 Flanzy M, Nouvelle méthode de vinification. Cr Acad Sci 21:934-938 (1935).

5 Jaime $A L$, Ruiz $M$ and Botta J, Experiencias a escala semi-industrial de vinificación en tinto con maceración carbónica no estricta, in /I Jornadas Técnicas de Rioja, vid y vino, July 1972. Haro-Logroño, La Rioja, Spain (1974).

6 Etaio I, Pérez Elortondo FJ, Albisu M, Gastón E, Ojeda M and Schlich P, Development of a quantitative sensory method for description of young red wines from Rioja Alavesa. J Sens Stud 23:631 - 655 (2008).

7 Lõrincz $\mathrm{G}$ and Vas $\mathrm{G}$, Examination of volatile components in carbonic macerated red wines. Vitic Enol Sci 53:18-21 (1998).

8 Flanzy C, Vinificación por maceración carbónica, in Enología: Fundamentos Científicos y Tecnológicos, $2 a$ edición, ed. by Flanzy C. Mundi-Prensa, Madrid, pp. 478-484 (2003).

9 Alvarez ML, Cotilla PA and Zamora E, Experiencia de maceración carbónica con la variedad Tempranillo en Tierra de Barros. Campañas 96-97, in Grupo de Trabajo de Experimentación en Viticultura y Enología. Reunión Anual 1998, 22 -24 April 1998. Laguardia and Zalla, Basque Country (1998).

10 Versini $\mathrm{G}$ and Tomasi $\mathrm{T}$, Confroto tra i componenti volatile dei vini rossi ottenutti con macerazione tradizionale e macerazione carbonica. Importanza differenziante del cinnamato di etile. L'enotecnico 9:595-600 (1983).

11 Ducruet V, Comparison of the headspace volatiles of carbonic maceration and traditional wine. Lebensm Wiss Technol 17:217-221 (1984).

12 Carroll DE, Effects of carbonic maceration on chemical, physical and sensory characteristics of muscadine wines. J Food Sci 51:1195-1196 (1986). 
13 Fuleki T, Application of carbonic maceration to change the bouquet and flavor characteristics of red table wines made from Concord grapes. Can Inst Food Sci Technol J 7:269-273 (1974).

14 Etaio I, Pérez Elortondo FJ, Albisu M, Gastón E, Ojeda M and Schlich $P$, Effect of winemaking process and addition of white grapes on sensory and physicochemical characteristics of young red wines. Aust J Grape Wine Res 14:211 - 222 (2008).

15 Pineau $N$, Schlich $P$, Cordelle $S$, Mathonnière $C$, Issanchou $S$, Imbert $A$ et al., Temporal Dominance of Sensations: Construction of the TDS curves and comparison with time-intensity. Food Qual Prefer 20:450-455 (2009)

16 Di Monaco R, Su C, Masi P and Cavella S, Temporal Dominance of Sensations: A review. Trends Food Sci Technol 38:104-112 (2014).

17 Pineau N and Schlich P, Temporal Dominance of Sensations (TDS) as a sensory profiling technique, in Rapid Sensory Profiling Techniques. Applications in New Product Development and Consumer Research, ed. by Delarue J, Lawlor B and Rogeaux M. Woodhead Publishing, Cambridge, pp. 269-306 (2015).

18 Labbe D, Schlich P, Pineau N, Gilbert F and Martin N, Temporal dominance of sensations and sensory profiling: A comparative study. Food Qual Prefer 20:216-221 (2009).

19 Deleris I, Saint-Eve A, Guo Y, Lieben P, Cypriani ML, Jacquet N, et al., Impact of swallowing on the dynamics of aroma release and perception during the consumption of alcoholic beverages. Chem Sens 36:701-713 (2011)

20 Saint-Eve A, Déléris I, Panouillé $M$, Dakowski F, Cordelle S, Schlich $P$, et al., How texture influences aroma and taste perception over time in candies. Chemosens Percept 4:32-41 (2011).

21 Dinnella C, Masi C, Zoboli G and Monteleone E, Sensory functionality of extra-virgin olive oil in vegetable foods assessed by Temporal Dominance of Sensations and descriptive analysis. Food Qual Prefer 26:141 - 150 (2012).

22 Ng M, Lawlor JB, Chandra S, Chaya C, Hewson L and Hort J, Using quantitative descriptive analysis and temporal dominance of sensations analysis as complementary methods for profiling commercial blackcurrant squashes. Food Qual Prefer 25:121-134 (2012).

23 Barron D, Pineau N, Matthey-Doret W, Ali S, Sudre J, Germain JC et al., Impact of crema on the aroma release and the in-mouth sensory perception of espresso coffee. Food Funct 3:923-930 (2012).

24 Albert A, Salvador A, Schlich P and Fiszman S, Comparison between temporal dominance of sensations (TDS) and key-attribute sensory profiling for evaluating solid food with contrasting textural layers: Fish sticks. Food Qual Prefer 24:111-118 (2012).

25 Vázquez-Araújo $\mathrm{L}$, Parker $\mathrm{D}$ and Woods $\mathrm{E}$, Comparison of temporal-sensory methods for beer flavor evaluation. J Sens Stud 28:387-395 (2013).

26 Varela P, Pintor A and Fiszman S, How hydrocolloids affect the temporal oral perception of ice cream. Food hydrocolloids 36:220-228 (2014).

27 Sokolowsky $M$ and Fischer $U$, Evaluation of bitterness in white wine applying descriptive analysis, time-intensity analysis, and tem- poral dominance of sensations analysis. Anal Chim Acta 732: 46-52 (2012).

28 Meillon S, Urbano $C$ and Schlich P, Contribution of the Temporal Dominance of Sensations method to the sensory description of subtle differences in partially dealcoholized red wines. Food Qual Prefer 20:490-499 (2009).

29 Meillon S, Viala D, Medel M, Urbano C, Guillot G and Schlich P, Impact of partial alcohol reduction in Syrah wine on perceived complexity and temporality of sensations and link with preference. Food Qual Prefer 21:732-740 (2010).

30 Sokolowsky M, Rosenberger A and Fischer U, Sensory impact of skin contact on white wines characterized by descriptive analysis, time-intensity analysis and temporal dominance of sensations analysis. Food Qual Prefer 39:285-297 (2015).

31 Boletín Oficial del Estado, Orden APA/3465/2004, de 20 de octubre, por la que se aprueba el Reglamento de la Denominación de Origen Calificada «Rioja» y de su Consejo Regulador (BOE 259 de 27/10/04, Madrid) (2004).

32 EEC, Council Regulation, List of laboratories authorized to undertake official analyses in the wine sector (C 46/10, of 19.2.1999) (List published pursuant to Article 79 of Council Regulation (EEC) No $822 / 87$ of 16 March 1987 on the common organization of the wine market). Off J Eur Commun C 046:181 - 192 (1999).

33 Dumolin ED, Azais BP and Guerain JT, Determination of sugar and ethanol content in aqueous products of molasses distilleries by near infrared spectrophotometry. J Food Sci 52:626-630 (1987).

34 EEC, European Official Methods. ECC Commission Regulation 2676/90, concerning the establishment of common analytical methods in the sector of wine (October 3, 1990). Off J Eur Commun L272:1-192 (1990).

35 Pineau N, Goupil de Bouillé A, Lepage M, Lenfant F, Schlich P, Martin N, et al., Temporal Dominance of Sensations: What is a good attribute list? Food Qual Prefer 26:159-165 (2012).

36 Drake MA, Yates MD, Gerard PD, Delahunty CM, Sheehan EM, Turnbull $\mathrm{RP}$, et al., Comparison of differences between lexicons for descriptive analysis of Cheddar cheese flavour in Ireland, New Zealand, and the United States of America. Int Dairy J 15:473-483 (2005).

37 Strauss S, The linguistic aestheticization of food: A cross-cultural look at food commercials in Japan, Korea, and the United States. J Pragmatics 37:1427-1455 (2005).

38 Tu VP, Valentin D, Husson F and Dacremont C, Cultural differences in food description and preference: Contrasting Vietnamese and French panellists on soy yogurts. Food Qual Prefer 21:602-610 (2010).

39 Pessina R, Boivin L, Moio L and Schlich P, Application of Temporal Dominance of Sensations to taste and flavor in wine, in 6th Pangborn Sensory Science Symposium, 7-11 August 2005, Harrogate (2005). Available: http://www.sensobase.fr/rmp05_liris/Pessina_rmp05.pdf [27 July 2015] 